Note

\title{
HAPLODIPLOID ANDROGENETIC BREEDING IN OAT: GENOTYPIC VARIATION IN ANTHER SIZE AND MICROSPORE DEVELOPMENT STAGE
}

Taniela De Cesaro ${ }^{1}$; Maria Irene Baggio' ${ }^{1}$; Silvia Andréia Zanetti ${ }^{1}$; Marilei Suzin ${ }^{1}$; Lizete Augustin $^{1 *}$; Sandra Patussi Brammer ${ }^{2}$; Edson Jair Iorczeski²; Sandra Cristina Kothe Milach ${ }^{3}$

${ }_{2}^{1}$ Universidade de Passo Fundo - C.P. 611 - 99001-970 - Passo Fundo - RS - Brasil.

${ }^{2}$ Embrapa Trigo - 99001-970 - Passo Fundo, RS - Brasil.

${ }^{3}$ Pioneer Sementes - C.P. 3031 - 99050-070 - Passo Fundo, RS - Brasil.

*Corresponding author<augustin@upf.br >

ABSTRACT: Oat (Avena spp.) is poorly responsive to the haplodiploidization process, which leads to the production of homozygous lines in one step, increasing breeding efficiency. Androgenetic haploids in small grain cereal crops are obtained from microspores cultured at the mononucleate stage, which can be identified by the size of anthers. In order to identify the appropriate anther size for in vitro culture, microspore cytological analyses were made in Avena sativa cultivars UPF 7, UPF 18, UFRGS 14, Stout and Avena sterilis CAV 3361, cultivated in growth chamber under controlled light and temperature conditions. Variation was observed within and among genotypes for anther size at each microspore developmental stage and according to the position of spikelets in the panicle. Architecture variation in panicle shape and non-linear microsporogenesis maturation increased the challenge of identifying potentially androgenetic oat anthers. Cytological screening before culture is critical in identifying microspores at the right stage for oat androgenesis.

Key words: androgenesis, anther culture, biotechnology, haploid breeding, microspores

\section{MELHORAMENTO POR HAPLODIPLOIDIZAÇÃO ANDROGENÉTICA: VARIAÇÃO GENOTÍPICA NOTAMANHO DAS ANTERAS E NO ESTÁGIO DE DESENVOLVIMENTO DOS MICRÓSPOROS EM AVEIA}

\begin{abstract}
RESUMO: A aveia (Avena spp.) tem sido pouco responsiva à haplodiploidização, um processo que aumenta a eficiência da seleção no melhoramento por gerar, em uma etapa, linhas puras homozigóticas. A fase mononucleada do micrósporo é critica para o sucesso da androgênese in vitro nos cereais de inverno e, em geral, pode ser inferida pelo tamanho da antera. Foram medidas anteras e analisados citológicamente micrósporos das cultivares de Avena sativa UPF 7, UPF 18, UFRGS 14, Stout e da linhagem CAV 3361 de Avena sterilis, cultivadas em câmaras de crescimento sob temperaturas dianoite variando de $16^{\circ} \mathrm{C}$ a $9^{\circ} \mathrm{C}$ e 12 horas de intensidade luminosa de $300 \mathrm{~mol} \mathrm{~m}^{-2} \mathrm{~s}^{-1}$. $\mathrm{O}$ tamanho das anteras em cada fase de desenvolvimento dos micrósporos variou significativamente entre genótipos e de acordo com a região de inserção das espiguetas na panícula. A variação na arquitetura da panícula e a maturação não linear das espiguetas aumentam as dificuldades para a identificação das anteras potencialmente androgenéticas e podem explicar, em parte, os baixos resultados da androgênese na aveia. Os dados mostram a necessidade de uma análise citológica prévia para auxiliar a determinar a fase ideal de desenvolvimento dos micrósporos potencialmente responsivos à cultura de anteras, para o uso da androgenese na aveia.

Palavras-chave: biotecnologia, cultura de anteras, haplóides, melhoramento vegetal
\end{abstract}

\section{INTRODUCTION}

In vitro haplodiploidization is a biotechnological strategy that increases selection efficiency and ac- celerates the achievement of uniform lines in breeding programs. The spontaneous or artificial duplication of the haploid genomes by colchicine treatment after in vitro culture of anthers or isolated microspores, allows 
the development, in just one step, of totally homozygous genotypes (Picard et al., 1993; Jähne et al., 1994; Vrinten et al., 1999).

Haplodiploidization in barley (Hordeum vulgare L.) and wheat (Triticum aestivum L.) has accelerated and increased the efficiency of breeding programs, genetics studies, molecular mapping and transformation and is routinely used at Embrapa Trigo (Peters et al., 1999; Moraes-Fernandes et al., 1999). Oat, however, has remained recalcitrant in the androgenetic process. Recently, in Finland, Kiviharju et al. (2005) reported the improvement of androgenetic green plantlet regeneration by anther culture, with acceptable rates in producing oat double-haploid plants.

The microspore stage is important for androgenesis because when the anthers are cultured in vitro, the switch from gametophytic to sporophytic routes happens only between the mononucleate and median binucleate stages. This period has been named by Smykal (2000) as the development window that opens to explore the competence of microspores for androgenesis. The oat floral morphology and the special sequence of microspore maturation in the panicles add difficulties in identifying anthers size with microspores at the appropriate stage, in comparison to barley and wheat, which mature from meiosis to microsporogenesis following a linear model, once their spike morphology makes easier the recognition of the right microspore stage.

Since androgenetic capacity is highly genotypedependent, before testing the new media proposed by Kiviharju et al. (2005), measurements of anther size and cytological analysis of developmental stage of microspores are also important. The objectives of this paper were to analyze anther size and microspore cytological stages to investigate their influence in the androgenetic process of three Brazilian oat genotypes as well as the foreing cultivar Stout and Avena sterilis L. both reported as having androgenetic capacity (Rines et al., 1997 and Kiviharju et al., 1997; 2000).

\section{MATERIAL AND METHODS}

The genotypes of the Avena sativa L included in this study were the Brazilian cultivars UPF 7, UPF 18, UFRGS 14 and the cultivar Stout. The genotype of the Avena sterilis L. was CAV 3361 line. Avena sterilis as well as Stout cultivar were reported as having androgenetic capacity by Rines et al (1997), Polsoni apud Rines et al. (1997) and Kiviharju et al. (1997; 2000).

The seeds were sowed in $7 \mathrm{~kg}$ pots with half forest and half mineral soil, plus chemical fertilizer $(10: 25: 25)$. At the beginning of tillering, ammonia was added as a nitrogen source. Ten seeds were sowed in each pot and, after emergency, the five most vigorous seedlings were kept to develop until maturity under 12 hours light, in growth chamber (Fitotron, model PGW 36, Conviron - Canada), at day- night temperatures varying from $16^{\circ} \mathrm{C}$ to $9^{\circ} \mathrm{C}$, and light intensity of $300 \mathrm{mmol} \mathrm{m}^{-2} \mathrm{~s}^{-1}$.

In order to identify the correct time to sample the oat panicles we used the method established by Wheatley et al. (1986). These authors used the distance between flag leaf (FL), flag leaf ${ }^{-1}\left(\mathrm{FL}^{-1}\right)$ and the last node to identify the microsporogenesis stages for barley immature spikes. Based on this method, samples were collected when the distance between the $\mathrm{FL}^{-1}$ and the last node is about one third of the distance between the last node and FL (Figure 1a). As the distance between $\mathrm{FL}$ and $\mathrm{FL}^{-1}$ increases, the flowering progress to maturity and the microspore developmental stages goes from meiosis to mature pollen grains. Since oat panicles do not mature in a linear model several panicles with different distances between $\mathrm{FL}$ and $\mathrm{FL}^{-1}$ were analyzed (Figure 1c). Five panicles of the three Brazilian

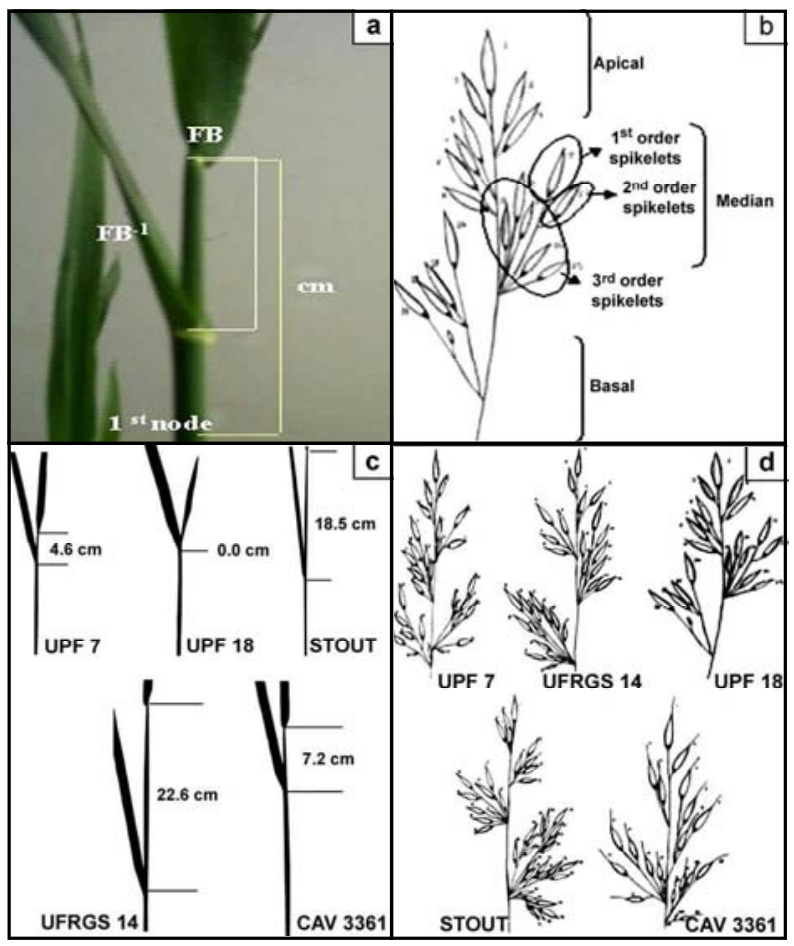

Figure 1- (a) Oat immature main tiller showing the flag leaf (FL), second leaf ( $\mathrm{FL}_{-} \mathrm{FL}^{-1}$ ) and the last node (no); (b) Spikelets at apical (1), median (2) and basal (3) panicle regions mapped before cytological analysis; (c) Distance between flag leaf (FL) and second leaf (FL$\left.F L^{-1}\right)$ in immature panicles for some of the studied genotypes and (d) variation among genotypes in panicle architecture. Passo Fundo, FAMV/UPF, 2001. 
cultivars, one from Stout and one from $A$. sterilis were fixed in alcohol and acetic acid (3:1) for 48 hours at room temperature and stored in alcohol $70 \%$ at $4^{\circ} \mathrm{C}$ for cytological analysis at different developmental stages varying from zero to $23.7 \mathrm{~cm}$ of distance between the FL and $\mathrm{FL}^{-1}$ (Figures $1 \mathrm{a}$ and $1 \mathrm{c}$ ). In spite of differences in the architecture of each of the 22 panicles analyzed, it was possible to identify three regions for all of them: apical, median and basal (Figures $1 \mathrm{~b}$ and $1 \mathrm{~d})$. The spikelets located at the apices of each ramification were named as first $\left(1^{\text {st }}\right)$, second $\left(2^{\text {nd }}\right)$ and third $\left(3^{\text {rd }}\right)$ order and numbered for identification of their location in the panicle in Figures $1 \mathrm{~b}$ and 1d. Each spikelet has usually a primary, a secondary and a tertiary flower and each flower has three anthers and one ovary.

The developmental stages of 100 microspores or pollen grains observed in the anthers of each flower were identified with an optical microscope (Zeiss). Two-hundred and twenty one anthers collected from primary flowers of 22 panicles of each genotype were measured in mm paper at Zeiss stereomicroscope, stained by acetic carmine $45 \%$ and analyzed. The microspore developmental stages were classified as follows: 1- postmeiotic haploid quartets; 2- young microspores; 3- central mononucleated microspores; 4dislocated mononucleated microspores; 5 - binucleated pollen grains to 6 - trinucleated and mature pollen grains (Table 1). The analysis of variance was done using the Statistical Analysis System package (SAS Institute, 1998) and means were compared by Duncan $(p<0.05)$.

\section{RESULTS AND DISCUSSION}

The mean size of the anthers in the primary florets of the analyzed spikelets varied from 1.03 in 'UPF 7' to $4.50 \mathrm{~mm}$ in Stout (Table 3). Increasing anther size logically means that they contain microspores at more advanced developmental stage. In spite of con- trolled temperature, light and humidity growth conditions of donor plants, the mononucleated (3) and late mononucleated (4) microspore developmental stages, both recommended as appropriated for in vitro anther culture were found in anthers presenting different sizes (Duncan, $p<0.05$ ) in all genotypes studied (Table 3 ). Higher frequencies were observed in all genotypes for anthers with microspores in these two stages, varying from $72.5 \%$ in 'UFRGS 14 ' to $61.1 \%$ in Stout (Table 3). However, only the frequency of anthers bearing microspores at late mononucleated was different from anthers at other stages (Duncan, $p<0.05$ ) (Table 1).

Anther size and microspore developmental stage also varied (Duncan, $p<0.05$ ) according to position of spikelets in the panicle. It was also observed that the size of anthers at each microspore developmental stage increased within genotypes (Duncan 5\%) when the insertion of the spikelets, from basal to median and apical regions of the panicle was taken into account (Figure 1d and Table 2).

The present results agree with the statement of Atanassov et al. (1995) that although size gives an indication of anther maturity stage, it is affected by anther position in the inflorescence, genotype and plant age. In spite of donor plants having been cultivated in controlled growth conditions, differences were found in the size of anthers with microspores at the same developmental stage. So it is possible that poor results obtained in several oat anther culture experiments may be partially explained by the difficulty of adequately monitoring microspore stage of development. Therefore a brief cytological analysis carried out prior to in vitro culture for each genotype and growing condition may help in defining the size of the anthers at the microspore mononucleated stage. Although for wheat and barley androgenesis, the linear spike and microspore maturation makes easier the identification of the appropriate anther size for in vitro culture, this recommendation cannot be used for oat.

Table 1 - Mean number and frequencies of anthers at each microspore developmental stage for 221 anthers analyzed in this experiment. Passo Fundo, FAMV/UPF, 2001.

\begin{tabular}{lcc}
\hline Microsporogenesis stage & Mean & Frequency \\
\hline & $4.00 \mathrm{~b}$ & $9.17 \mathrm{~b}$ \\
1- Quartets & $5.25 \mathrm{~b}$ & $8.80 \mathrm{~b}$ \\
2- Young microspores & $4.00 \mathrm{~b}$ & $10.76 \mathrm{~b}$ \\
3- Central mononucleated microspores & $25.20 \mathrm{a}$ & $54.12 \mathrm{a}$ \\
4- Dislocated mononucleated microspores & $4.20 \mathrm{~b}$ & $9.30 \mathrm{~b}$ \\
5- Binucleated pollen grains & $5.50 \mathrm{~b}$ & $8.97 \mathrm{~b}$ \\
\hline 6- Trinucleated and mature pollen grains & & \\
\hline
\end{tabular}

Numbers followed by the same letter do not differ (Duncan, $p<0.05$ ). 
Table 2 - Mean anther size and developmental stage of microspores in spikelets located at apical, median and basal regions of the panicle showed in Figure 1b, for each genotype. Passo Fundo, FAMV/UPF, 2001.

\begin{tabular}{|c|c|c|c|c|c|c|}
\hline Panicle region & Microspore development stage & UPF 7 & UPF 18 & UFRGS 14 & STOUT & CAV 3361 \\
\hline & & 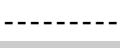 & & $--\mathrm{mm}--$ & & \\
\hline \multirow{6}{*}{ Apical } & 1 Meiosis and quartets & & & & & \\
\hline & 2 Young microspores & & $1.50 \mathrm{c}$ & & & \\
\hline & 3 Mononucleate central microspores & & $1.80 \mathrm{c}$ & & & \\
\hline & 4 Mononucleate late microspores & $2.34 \mathrm{a}$ & $2.65 \mathrm{~b}$ & $3.32 \mathrm{~b}$ & $3.80 \mathrm{~b}$ & $3.23 \mathrm{~b}$ \\
\hline & 5 Binucleate pollen grain & $2.46 \mathrm{a}$ & $3.72 \mathrm{a}$ & $3.50 \mathrm{~b}$ & $4.50 \mathrm{a}$ & $3.00 \mathrm{c}$ \\
\hline & 6 Trinucleate pollen (mature). & $2.50 \mathrm{a}$ & & $4.17 \mathrm{a}$ & $4.50 \mathrm{a}$ & $3.57 \mathrm{a}$ \\
\hline \multirow{6}{*}{ Medium } & Meiosis and quartets & & & & & \\
\hline & Young microspores & $1.20 \mathrm{c}$ & & & & \\
\hline & Mononucleate central microspores & $1.40 \mathrm{c}$ & $1.52 \mathrm{~d}$ & $2.00 \mathrm{c}$ & & $2.50 \mathrm{~b}$ \\
\hline & Mononucleate late microspores & $1.99 \mathrm{~b}$ & $2.00 \mathrm{c}$ & $3.32 \mathrm{~b}$ & $3.79 \mathrm{~b}$ & $2.78 \mathrm{ba}$ \\
\hline & Binucleate pollen grains & $2.50 \mathrm{a}$ & $2.61 \mathrm{~b}$ & $4.00 \mathrm{a}$ & $4.35 \mathrm{a}$ & $2.95 \mathrm{a}$ \\
\hline & Trinucleate pollen grains (mature) & & $3.67 \mathrm{a}$ & & & \\
\hline \multirow{6}{*}{ Basal } & Meiosis and quartets & $1.04 \mathrm{c}$ & $1.40 \mathrm{c}$ & $1.13 \mathrm{~d}$ & & $1.57 \mathrm{~d}$ \\
\hline & Young microspores & $1.11 \mathrm{c}$ & $0.96 \mathrm{~d}$ & $1.52 \mathrm{~b}$ & & $1.50 \mathrm{~d}$ \\
\hline & Mononucleate central microspores & $1.32 \mathrm{~b}$ & & $1.86 \mathrm{~b}$ & $2.55 \mathrm{~b}$ & $2.07 \mathrm{c}$ \\
\hline & Mononucleate late microspores & $1.84 \mathrm{a}$ & $2.39 \mathrm{~b}$ & $2.64 \mathrm{a}$ & $3.28 \mathrm{a}$ & $2.50 \mathrm{~b}$ \\
\hline & Binucleate pollen grains & & $3.50 \mathrm{a}$ & & & $3.20 \mathrm{a}$ \\
\hline & Trinucleate pollen grains (mature) & & & & & \\
\hline
\end{tabular}

Means followed by the same letter do not differ (Duncan test, $p<0.05$ ).

Table 3 - Microspore stage and mean anther size of oat genotypes. Passo Fundo, FAMV/UPF, 2001.

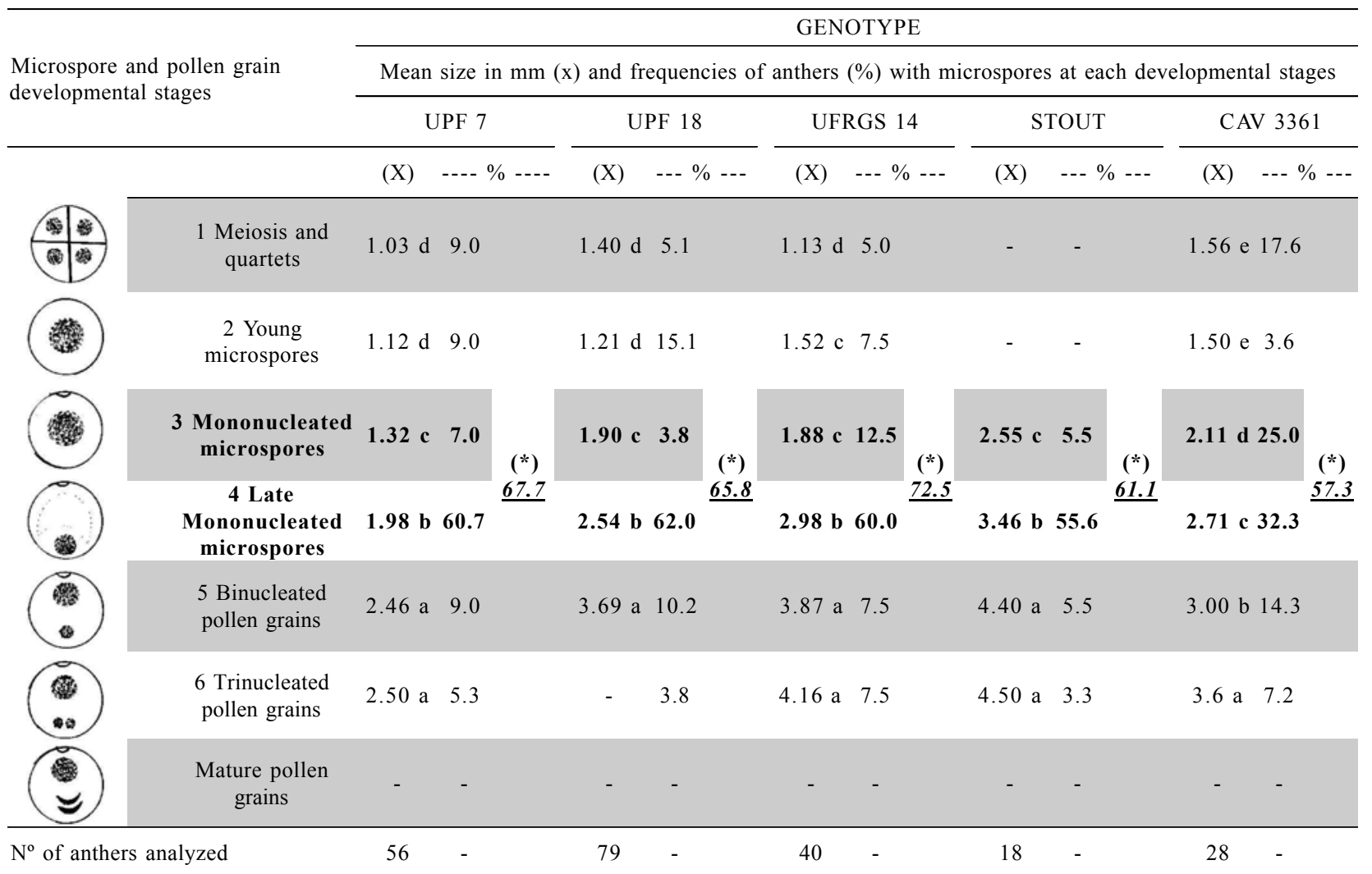

Means followed by the same letter do not differ (Duncan test, $p<0.05) .(*)$ These values represent the total $\%$ of microspores at phase 3 and 4 , indicated as appropriate for androgenesis. 
Due to morphophysiological variation of oat panicles and the non linear microspore maturation sequence, the use of anther size alone for the identification of near ideal microspore developmental stage is not an efficient selection criterion. These results indicated the need of a more accurate attention of anther size and an intense cytological screening to evaluate the adequate microspore developmental stage for androgenetic experiments in Avena as well as in other species with non-linear inflorescence maturation.

\section{ACKNOWLEDGMENTS}

To Embrapa Trigo and Universidade de Passo Fundo for use of biotechnology laboratories and growth chambers facilities, CNPq, FINEP for the research grants and to CAPES for a scholarship to $\mathrm{T}$. De Cesaro from 2000 to 2002.

\section{REFERENCES}

ATANASSOV, A.; ZAGORSKA, P.; BOYADJIEV, P.; DJILIANOV, D. In vitro production of haploid plants. World Journal of Microbiology and Biotechnology, v.11, p.400-408, 1995. JÄHNE, A.; BECKER, D.; BRETTSCHNEIDER, R.; LÖRS, H. Regeneration of transgenic microspore-derived, fertile barley. Theoretical and Applied Genetics, v.89, p.525-533, 1994. KIVIHARJU, E.; MOISANDER, S.; LAURILA, J. Improved green plant regeneration rates from anther culture and agronomic performance of some DH lines. Plant Cell, Tissue and Organ Culture, v.81, p.1-9, 2005.

KIVIHARJU, E.; PUOLIMATKA, M.; PEHU, E. Regeneration of anther-derived plants of Avena sterilis. Plant Cell Reports, v.48, p.147-152, 1997.
KIVIHARJU, E.; PUOLIMATKA, M.; SAASTAMOINEN, M. Extension of anther culture to several genotypes of cultivated oats. Plant Cell Reports, v.19, p.674-679, 2000.

MORAES-FERNANDES, M.I.B.; STIVAL, A.L.; BRAMMER, S.P.; GRANDO, M.F. Haploidização: genética e melhoramento. In: TORRES, A.C.; CALDAS, L.S (Org.) Cultura de tecidos e transformação genética de plantas. Brasília: Embrapa/ CNPH, 1999. p.613-650.

PETERS, J.A.; BOBROWSKI, V.L.; ROSINHA, G.M.S. Produção de haplóides e duplo haplóides. In: TORRES, A.C.; CALDAS, L.S. (Org.) Cultura de tecidos e transformação genética de plantas. Brasília: Embrapa/CNPH, 1999. p.569-610.

PICARD, E.; CRAMBES, E.; MIHAMOU-ZIYYAT, A. L'haplodiploidisation: un outil multi-usage pour la génétique et l'amélioration des cereals. Orsay: Université de Paris Sûd, 1993. p.355-359.

RINES, H.W.; RIERA-LIZARAZU, O.; NUNEZ, V.M.; DAVIS, D.W.; PHILLIPS, R.L. Oat haploids from anther culture and from wide hybridizations. In: MOHANJAIN, S.; SOPORY, S.K.; VEILLEUX, R.E. (Org.) In vitro haploid production in higher plants. Dordrecht: Kluwer Academic, 1997. p.205-221.

SAS INSTITUTE. SAS user's guide: statistical analysis system; release 6.12. Cary: SAS Institute, 1998.

SMYKAL, P. Pollen embryogenesis: the stress mediated switch from gamatophytic to sporophytic development; current status and future prospects Biologia Plantarum, v.43, p.481-489, 2000 .

VRINTEN, P.L.; NAKAMURA, T.; KASHA, K.J. Characterization of cDNA expressed in the early stages of microspore embryogenesis in barley (Hordeum vulgare L.). Plant Molecular Biology, v.41 p.455-463, 1999.

WHEATLEY, W.G.; MARSOLAIS, A.A.; KASHA, K.J. Microspore growth and anther staging in barley anther culture. Plant Cell Reports, v.5, p.47-49, 1986.

Received May 03, 2007

Accepted April 14, 2008 